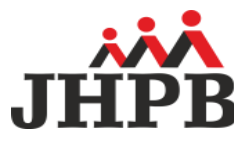 \\ Journal of Health Promotion and Behavior (2021), 06(03): 201-211 \\ Masters Program in Public Health, Universitas Sebelas Maret
}

\section{Meta-Analysis the Effect of Screen Time on the Risk of Overweight in Children and Adolescents in Asia}

\author{
Nita Putriasti Mayarestya1), Eti Poncorini Pamungkasari²), \\ Hanung Prasetya ${ }^{3)}$
}

\author{
${ }^{1)}$ Masters Program in Public Health, Universitas Sebelas Maret \\ 2)Faculty of Medicine, Universitas Sebelas Maret \\ 3)Study Program of Acupuntur, Health Polytechnics, Ministry of Health Surakarta
}

\section{ABSTRACT}

Background: Overweight and obesity are a growing threat to the well-being of the world's children. In 2010-2016, the prevalence of underweight was growing rapidly among children and adolescents in Asia. With the development of technology, screen time has become a behavior that can have a negative effect on children and adolescents if it is associated with being overweight. One in three internet users in the world are children and adolescents under the age of 18 years. Asia has the highest rates of child internet use globally. Several studies in Asian countries reported high screen time in children and adolescents. On average, children and adolescents in Asia have screen time duration $>2$ hours per day outside of study/school time. This study aims to analyze the effect of screen time duration on overweight children and adolescents in Asia.

Subjects and Method: This research is a systematic review and meta-analysis conducted using PRISMA flow diagrams. Search articles through journal databases including: Google Schoolar, Science Direct, Researchgate and PubMed by selecting articles published in 2010-2021. "Screen Time" OR "Sedentary Behavior" AND "Overweight" OR "Body Mass Index" OR "BMI" OR "Weight" OR "Obesity" AND "Children" OR "Child” OR "Adolescent" OR "Teen" AND "Cross Sectional". Inclusion criteria were articles using English or Indonesian, full paper articles with cross sectional design, 5-19 years old sample, screen time duration $>2$ hours per day, research locations in Asia. Eligible articles were analyzed using the Revman 5.3 application.

Results: A meta-analysis of 11 cross-sectional articles concluded that children and adolescents with screen time duration $>2$ hours per day had a 1.63 times greater risk of being overweight than children and adolescents with screen time duration 2 hours $(\mathrm{aOR}=1.63 ; 95 \% \mathrm{CI}=1.13)$. up to 2.35; $\mathrm{p}=0.009$ ).

Conclusion: Children and adolescents with screen time duration $>2$ hours per day are at risk of being overweight.

Keywords: Screen time, overweight

\section{Correspondence:}

Nita Putriasti Mayarestya. Masters Program in Public Health. Universitas Sebelas Maret, Jl.Ir. Sutami 36A, Surakarta 57126, Central Java, Indonesia. Email: nmayarestya@gmail.com Mobile: 085252493555 .

\section{Cite this as:}

Mayarestya NP, Pamungkasari EP, Prasetya H (2021). Meta-Analysis the Effect of Screen Time on the Risk of Overweight in Children and Adolescents in Asia. J Health Promot Behav. 06(03): 201211. https://doi.org/10.26911/thejhpb.2021.06.03.04.

(i) (2) Journal of Health Promotion and Behavioris licensed under a Creative Commons

Attribution-NonCommercial-ShareAlike 4.o International License.

\section{BACKGROUND}

Overweight and obesity are a growing threat to the well-being of the world's child- ren. In 2016, more than 340 million children and adolescents aged 5-19 years were overweight and obese (UNICEF, 2020). The 
World Health Organization (2014) estimates that the increase in overweight and obesity in children mostly comes from developing countries and the rate of increase is faster when compared to developed countries.

Based on a meta-analysis study on the prevalence of overweight and obesity in childhood (5-11 years) and adolescents (1219 years) in Asian countries reported changes in the epidemiological transition and an increase in cases in several countries in Asia. The prevalence of overweight in children is $11.2 \%$ and in adolescents is 14.6\% (Mazidi et al., 2018). In the AsiaPacific region, obesity rates in children and adolescents vary widely, with the highest being $6.3 \%$ in New Zealand and second at 14.1\% in Brunei Darussalam. In 2010-2016, the prevalence of underweight was growing rapidly among children and adolescents in Asia. In India there was an increase in weight prevalence of more than $4.4 \%$ to $6.8 \%$ and Cambodia from $7.3 \%$ to $11.3 \%$ (OECD/WHO, 2020).

In general, the prevalence of overweight and obesity in children and adolescents is caused by excessive food intake that contains high fat and sugar and is balanced with low physical activity (Mistry \& Puthussery, 2015). According to Jannah et al., (2021) adolescents who have short sleep duration and low physical activity have a risk of overweight and obesity.

As technology develops, screen time has become a behavior that can have a negative impact on children and adolescents when it comes to health. The behavior of using long screen durations can trigger various health problems such as child development, overweight or obesity and mental health (Ashton \& Beattie, 2019). Screen time is defined as the time spent on screen device activities such as watching television/videos, playing video games using computers/laptops/mobile phones or smartphones (De Lucena et al., 2015).

Based on statistical data regarding internet access users in the world in 2021, Asia occupies the highest percentage at $53.4 \%$ compared to other regional regions (Internet World Stats, 2021). United Nations Children's Fund's report State of the World's Children 2017: Children In A Digital World, one in three internet users in the world are children and adolescents under the age of 18 years. Children and youth ages 8-18 have an average of 7.5 hours per day in front of a screen for entertainment, 4.5 hours of which for watching television other than for educational or study purposes (CDC, 2021).

Globally, children in Asia have the highest internet usage compared to other regions. There are $98 \%$ of children aged 3-8 years in Southeast Asia already using mobile devices. Most children spend 1 hour in one sitting when using a screen device (Unantenne, 2014). According to Mazidi et al., (2018) overweight and obesity in children and adolescents in Asia have increased cases along with the transition of nutrition, urbanization and increased sedentary behavior and lack of physical activity due to lack of play areas, increased duration of screen time such as watching television. television and playing video games.

Based on previous research in several countries in Asia, there are $42.4 \%$ of urban adolescents and $25 \%$ of adolescents in the suburbs of China who eat while watching television (Jiang et al., 2014). Teenagers in Turkey have a very high frequency of playing video games and have a habit of consuming drinks during video game playing sessions in adolescents with BMI above 95\% (Oflu \& Yalcin, 2019). The presence of television facilities in the bedroom and the behavior of watching television more than 2 hours per day are associated with waist cir- 
cumference, fat mass, and abdominal subcutaneous adiposity (Staiano et al., 2013).

The development of screen device technology and the ease of digital/internet access have resulted in children and adolescents choosing to spend more time in front of screens which can have an impact on health. Recommendations for limiting screen time for children and adolescents to no more than 2 hours per day issued by the American Academy of Pediactrics in 2016 are still a matter of debate regarding the appropriateness and accuracy of these limits.

With the changing lifestyles of children and adolescents in Asia along with the development of screen device technology and the negative impact on body weight, researchers are interested in studying the effect of screen time duration on overweight children and adolescents in Asia. The data obtained will be analyzed using meta-analysis and systematic review by synthesizing the results of studies conducted to reduce bias.

\section{SUBJECTS AND METHOD}

\section{Study Design}

This study uses a systematic review and meta-analysis study design. Using the PRISMA flow chart guidelines. Article searches were carried out using journal databases including: PubMed, Science Direct, Researchgate, Google Schoolar and SpringerLink articles in the 2010-2021 range with the keywords ("Screen Time" OR "Sedentary Behavior") AND ("Overweight" OR "Body Mass Index"OR "BMI" OR "Weight" OR "Obesity") AND ("Children" OR “Child”) AND (“Adolescent” OR “Teen”) AND "Cross Sectional”.

\section{Inclusion Criteria}

This study has inclusion criteria, including: Full paper articles with Cross Sectional studies, articles using English or Indone- sian, samples aged 5-19 years, screen time duration >2 hours/ day, and research locations are in the Asian region

\section{Exclusion Criteria}

This study has exclusion criteria, including: descriptive/systematic review and metaanalysis, articles are not full text, research outcomes are not overweight and articles do not include adjusted odds ratio (aOR).

\section{Operational Definition of Variables}

The formulation of the problem in this study was carried out by considering the eligibility criteria defined using the PICO, namely, Population: children and adolescents aged 5-19 years, Intervention: screen time duration $>2$ hours per day, Comparison: screen time duration 2 hours per day, and Outcome: overweight. Screen Time is defined as the time used to perform screen device activities such as watching television/videos, playing video games and using computers/laptops/smartphones (De Lucena et al., 2015).

Overweight is body weight that exceeds normal weight with BMI status 1 SD ( $\geq 25$ $\mathrm{kg} / \mathrm{m}^{2}$ ) (WHO, 2020).

\section{Instruments}

The instruments in this study were calibrated weight and microtoise scales and a questionnaire regarding activities using a screen device as a screen time measurement tool.

\section{Data Analysis}

Data analysis in this study was carried out using the Review Manager application (RevMan 5.3). Data were analyzed based on variations between studies by determining the use of random effects analysis models. In this study, $\mathrm{I}^{2}$ was used to quantify the dispersion. The results of the data analysis are in the form of the effect size value of the heterogeneity of the study, which later results from the data that has been analyzed and interpreted in the form of forest plots and funnel plots. 


\section{RESULTS}

Research from the primary study related to the effect of screen time on overweight, there are 11 articles with a total sample of 13015 participants. Articles were obtained from 4 Asian regional regions, namely, 3 East Asia, 4 South Asia, 1 East Asia and 3 Southeast Asia. Each study had a sample of more than 100 participants.

The search for articles was carried out using a database based on the PRISMA flow diagram, which can be seen in Figure 1 . The study quality assessment was carried out qualitatively and quantitatively. Assessment of research quality using the Critical Appraisal Skills Program (CASP) can be seen in Table 1. Each of the 12 questions was answered with the answer choices: Yes, No and Unclear. After assessing the quality of the study, 11 articles included in the quantitative synthesis process of the metaanalysis were analyzed using RevMan 5.3.

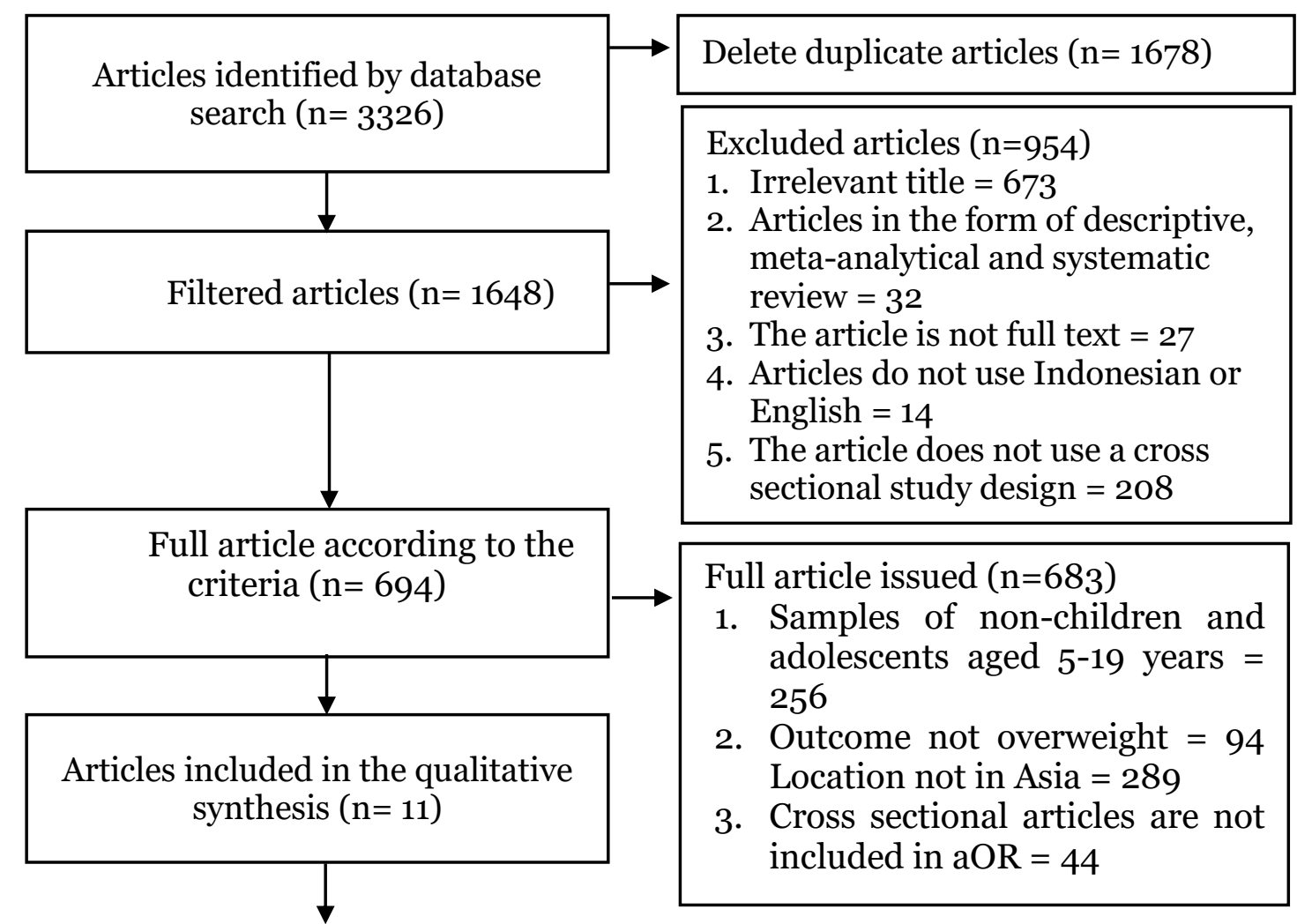

Full article according to the criteria $(n=11)$

Figure 1. PRISMA Flow Diagram 
Table 1. Research Quality Assessment of the Effect of Screen Time on Overweight

\begin{tabular}{|c|c|c|c|c|c|c|c|}
\hline No. & Question & $\begin{array}{c}\text { El-Kassas } \\
\text { \& Ziade } \\
(2017)\end{array}$ & $\begin{array}{c}\text { Febriani \& } \\
\text { Sudarti } \\
\text { (2019) }\end{array}$ & $\begin{array}{c}\text { Piryani } \\
\text { et al. } \\
\text { (2016) }\end{array}$ & $\begin{array}{c}\text { Ngunyen } \\
\text { et al. } \\
\text { (2016) }\end{array}$ & $\begin{array}{c}\text { Karma } \\
\text { ni et al. } \\
(2018)\end{array}$ & $\begin{array}{c}\text { Chaulaga } \\
\text { in et al. } \\
(2020)\end{array}$ \\
\hline 1. & Are the problems discussed in the research clearly focused? & 1 & 1 & 1 & 1 & 1 & 1 \\
\hline 2. & $\begin{array}{l}\text { Is the cross-sectional research method appropriate to } \\
\text { answer the research question? }\end{array}$ & 1 & 1 & 1 & 1 & 1 & 1 \\
\hline 3. & Is the research subject selection method clearly written? & 1 & 1 & 1 & 1 & 1 & 1 \\
\hline 4. & $\begin{array}{l}\text { Does the research sampling method not create bias } \\
\text { (selection)? }\end{array}$ & 1 & 1 & O & 1 & $\mathrm{O}$ & 1 \\
\hline 5. & $\begin{array}{l}\text { Does the research sample taken represent the designated } \\
\text { population? }\end{array}$ & 1 & 1 & 1 & 1 & 1 & 1 \\
\hline 6. & Was the sample size based on pre-research considerations? & 1 & 1 & 1 & 1 & 1 & 1 \\
\hline 7. & Was a satisfactory response achieved? & 1 & 1 & 1 & 1 & 1 & 1 \\
\hline 8. & Are the research instruments reliable? & 1 & 1 & 1 & 1 & 1 & 1 \\
\hline 9. & Was statistical significance assessed? & 1 & 1 & 1 & 1 & 1 & 1 \\
\hline 10. & Was a confidence interval given for the main outcome? & 1 & 1 & 1 & 1 & 1 & 1 \\
\hline 11. & Have confounding factors been taken into account? & 1 & 1 & 1 & 1 & 1 & 1 \\
\hline 12 & Are the results applicable to your research? & 1 & 1 & 1 & 1 & 1 & 1 \\
\hline Total & & 12 & 12 & 11 & 12 & 11 & 12 \\
\hline
\end{tabular}

Note: $1=$ Yes, $0=$ No 
Table 1. Research Quality Assessment of the Effect of Screen Time on Overweight

\begin{tabular}{|c|c|c|c|c|c|c|}
\hline No. & Question & $\begin{array}{c}\text { Moradi } \\
\text { et al. } \\
(2016)\end{array}$ & $\begin{array}{c}\text { Li et } \\
\text { al. } \\
(2015)\end{array}$ & $\begin{array}{c}\text { Nawab } \\
\text { et al. } \\
\text { (2014) }\end{array}$ & $\begin{array}{c}\text { Hadianfard } \\
\text { et al. } \\
(2021)\end{array}$ & $\begin{array}{l}\text { Bhiswalata } \\
\text { et al. (2010) }\end{array}$ \\
\hline 1. & Are the problems discussed in the research clearly focused? & 1 & 1 & 1 & 1 & 1 \\
\hline 2. & $\begin{array}{l}\text { Are cross-sectional research methods appropriate to answer the research } \\
\text { question? }\end{array}$ & 1 & 1 & 1 & 1 & 1 \\
\hline 3. & Is the research subject selection method clearly written? & 1 & 1 & 1 & 1 & 1 \\
\hline 4. & Does the research sampling method not create bias (selection)? & 1 & 1 & 1 & o & 1 \\
\hline 5. & Does the research sample taken represent the designated population? & 1 & 1 & 1 & 1 & 1 \\
\hline 6. & Was the sample size based on pre-research considerations? & 1 & 1 & 1 & 1 & 1 \\
\hline 7. & Was a satisfactory response achieved? & 1 & 1 & 1 & 1 & 1 \\
\hline 8. & Are the research instruments reliable? & 1 & 1 & 1 & 1 & 1 \\
\hline 9. & Was statistical significance assessed? & 1 & 1 & 1 & 1 & 1 \\
\hline 10. & Was a confidence interval given for the main outcome? & 1 & 1 & 1 & 1 & 1 \\
\hline 11. & Have confounding factors been taken into account? & 1 & 1 & 1 & 1 & 1 \\
\hline 12 & Are the results applicable to your research? & 1 & 1 & 1 & 1 & 1 \\
\hline Total & & 12 & 12 & 12 & 11 & 12 \\
\hline
\end{tabular}

Note: $1=$ Yes, $0=$ No 
Mayarestya et al./ Screen Time and the Risk of Overweight in Children and Adolescents

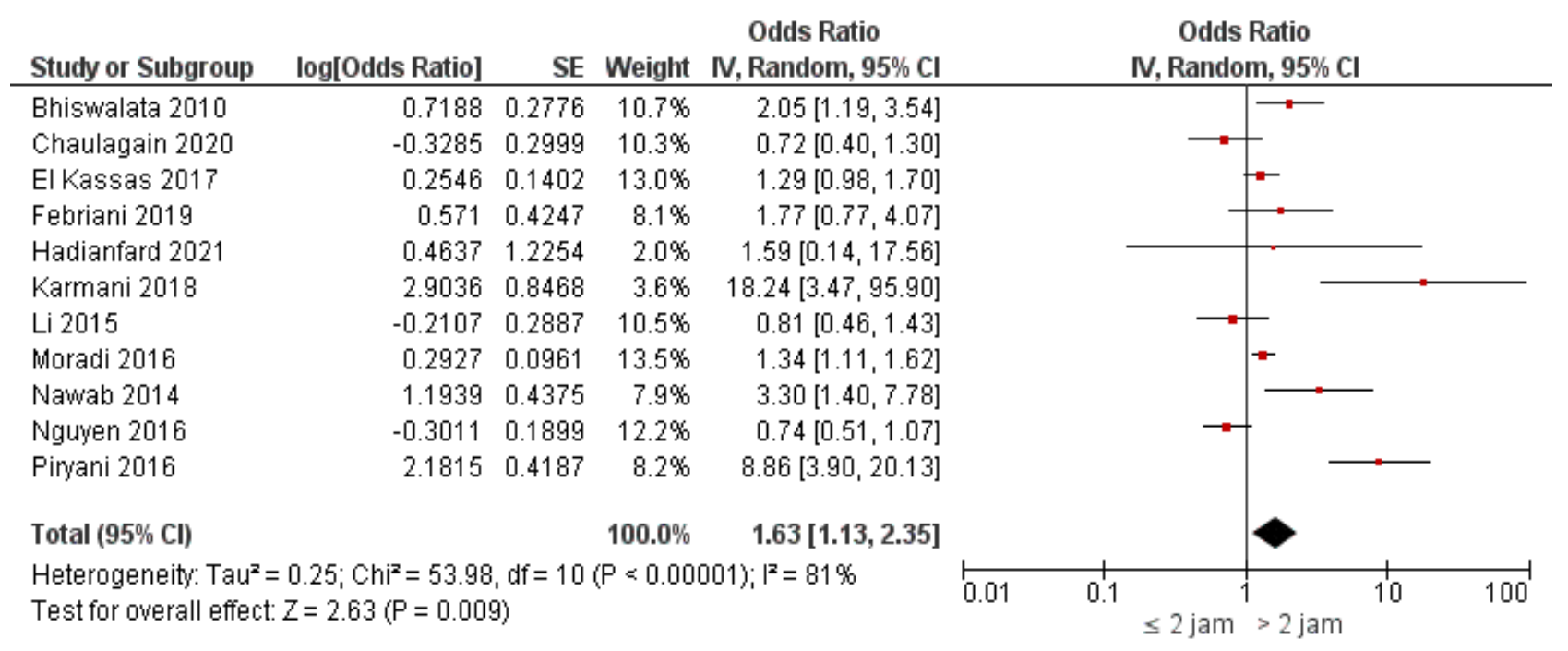

Figure 2. Forest plot Screen time against overweight

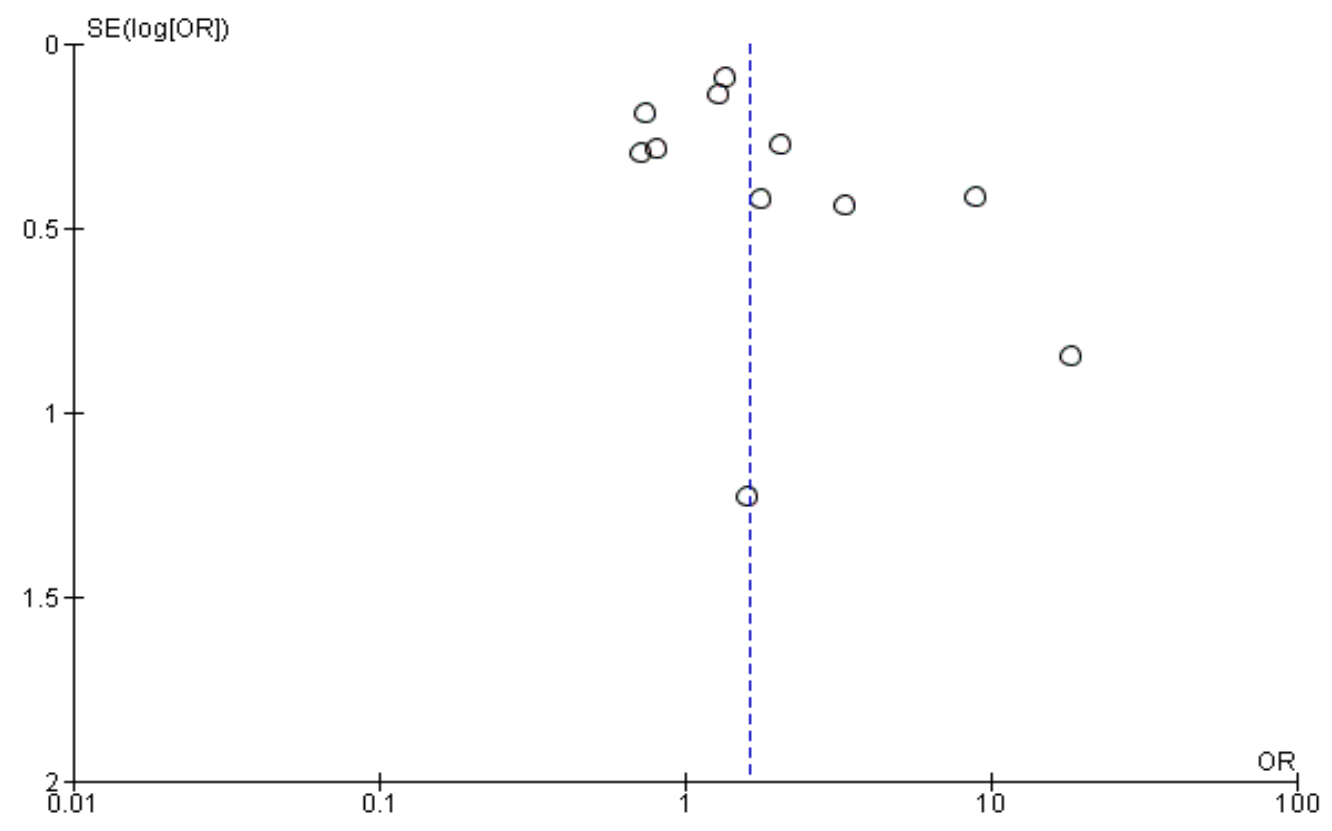

Figure 3. Funnel plot Screen time against overweight

\section{a. Forest plot the effect of Screen time on overweight}

Interpretation of the results of the metaanalysis process can be seen through the forest plot. Figure 2 shows that children and adolescents with screen time duration $>2$ hours have a risk of being overweight 1.63 times more than children and adolescents with screen time duration 2 hours $(\mathrm{aOR}=$ $1.63 ; 95 \% \mathrm{CI}=1.13$ to $2.35 ; \mathrm{p}=0.009)$. The value of the heterogeneity of the data can be seen in the value of $\mathrm{I}^{2}$. The results of the forest plot above show that the heterogeneity is high at $\mathrm{I}^{2}=81 \%$ so that the analysis used is a random effect model.

\section{b. Funnel plot the effect of Screen time on overweight}

Funnel plot is a result that can describe the distribution of research data against publication bias or standard error. Based on Fi- 
gure 3. the effect of screen time duration on body weight shows that there is a publication bias which is indicated by the asymmetry of the right and left plots. There are 5 plots on the left with SE between o and 0.5; 5 plots on the right with SE o to 1 ; and there is 1 plot touching the effect line.

\section{DISCUSSION}

The development of technology in display devices is increasing along with the higher human needs. Various screen device innovations are produced to make everyday life easier. There are various types of screen devices available such as televisions, computers, tablets, laptops, and smartphones that are equipped with a variety of interesting applications that can help work, education and entertainment so that people spend more time in front of the screen. The development of screen device technology can have an impact on changes in lifestyle and behavior that can affect health if done for a long time.

The use of a long duration of screen time is balanced with food consumption behavior and unhealthy eating patterns and low physical activity can be at risk of overweight and obesity (Chassiakos et al., 2016). According to Kelishadi et al. (2017) screen time can trigger children and adolescents to consume sweet foods or drinks and fast food. The presence of advertisements on television and the internet regarding energy-dense foods and types of food with low nutritional value can affect food intake in children and adolescents.

The presence of television in the bedroom can cause the intensity and duration of screen time to be out of control. Children and adolescents with television facilities in the room and having screen time duration $>2$ hours per day affect waist circumference, fat mass, and abdominal subcutaneous adiposity (Staiano et al., 2013). A similar study conducted by Chaput (2014) on children in Ottawa found that the presence of a screen device such as a television, computer or video game in the bedroom had a much higher percentage of body fat than children without a screen device in the bedroom and increase screen time.

Certain types of smartphone use behavior can affect food intake. Taking photos of food during meal times can distract one's attention from the food, resulting in one failing to distinguish between food portion sizes (Yong et al., 2021). The use of the latest technology and the presence of distractions during meals can affect the increase in calorie intake and lack of movement/physical activity. Smartphone use is comparable to television use which has an impact on decreasing daily energy expenditure caused by the length of time spent on smartphones (Gonçalves et al., 2019).

According to Oflu \& Yalcin (2019), the activity of playing video games can affect the consumption of sugary drinks. Doing activities in front of a computer screen can reduce a person's attention to food, allowing for more food intake and decreased eating memory (Higgs, 2015).

The use of screen devices can make a person experience "unconscious eating" mechanisms that affect physiological hunger and satiety signals. When children and adolescents use screen devices and eat at the same time, children and adolescents tend to choose energy-dense foods or snacks so that they are less careful about the amount of food or unconsciously overeat (Bickham et al., 2013).

Technological developments in the digital era do not always produce a positive impact. Seeing the enormous benefits of technology in everyday life, taking steps to eliminate or stop using screen devices is difficult. So that in order to prevent and 
minimize the adverse effects caused by exposure to screen devices without having to eliminate these activities, it is necessary to do this.

Screen time behavior towards the risk of being overweight is mostly experienced by children and adolescents. If it is associated with the family environment, the duration of long screen time on the behavior of parents who are accustomed to having long screen time also affects the duration of screen time in children (Watanabe et al., 2016). Applying the concept of parenting by providing examples of healthy living behavior balanced by still controlling children's activities can help control the duration of screen time. Improving parenting practices, parents' self-efficacy or changing parenting styles can also be promising approaches to reduce children's screen time (Xu et al., 2015).

\section{AUTHOR CONTRIBUTION}

Nita Putriasti Mayarestya is the main researcher who selects the topic, searches and collects research data. Eti Poncorini Pamungkasari and Hanung Prasetya analyzed data and reviewed research documents.

\section{FUNDING AND SPONSORSHIP}

This study is self-funded.

\section{CONFLICT OF INTEREST}

There is no conflict of interest in this study.

\section{ACKNOWLEDGMENT}

The researcher would like to thank all those who have helped in compiling this article and also thank the database providers PubMed, Science Direct, Researchgate, Google Schoolar and SpingerLink.

\section{REFERENCES}

Ashton JJ, Beattie RM (2019). Screen Time In Children And Adolescents: Is There
Evidence To Guide Parents And Policy. Lancet Child Adolesc. Health. https://doi.org/10.1016/S23524642(1 9)30062-8.

Bickham DS, Blood EA, Walls CE, Shrier LA, Rich M (2013). Characteristics Of Screen Media Use Associated With Higher BMI In Young Adolescents. Pediatrics. 131(5): 935-941. https://doi.org/10.1542/peds.20121197

Bishwalata R, Singh AB, Singh AJ, Devi L U, Singh RKB (2010). Overweight And Obesity Among Schoolchildren In Manipur, India. Natl Med J India. 23(5): 263-266. http://www.ncbi.nlm.nih.gov/pubmed/21250579

CDC (2021). Infographics - Screen Time vs. Lean Time | DNPAO | CDC. https://www.cdc.gov/nccdphp/dnpao/multi media/infographics/getmoving.html

Chassiakos YR, Radesky J, Christakis D, Moreno MA, Cross C, Hill D, Ameenuddin NH, et al. (2016). Children And Adolescents And Digital Media. Pediatrics. 138(5). https://doi.org/10.1542/peds.2016-2593

Chaulagain K (2021). The Burden Of Overweight And Its Risk Factors In Urban Nepalese School Adolescents: A Cross-Sectional Study. Int J Qual Health Care. 4(4). https://doi.org/10.23880/jqhe-16000230

De Lucena JMS, Cheng LA, Cavalcante TL M, da Silva VA, de Farias Júnior JC (2015). Prevalência De Tempo Excessivo De Tela E Fatores Associados Em Adolescentes. Rev Paul Pediatr. 33(4): 407-414. https://doi.org/10.1016/j.rpped.2015.04.001

El-Kassas G, Ziade F (2017). Exploration Of The Risk Factors Of Generalized And Central Obesity Among Adolescents In North Lebanon. Int J Environ Res Public Health. https://doi.org/10.1155/2017/2879075. 
Febriani D, Sudarti T (2019). Fast Food As Drivers For Overweight And Obesity Among Urban School Children At Jakarta, Indonesia. Jurnal Gizi Dan Pangan. 14(2): 99-106. https://doi.org/10.25182/jgp.2019.14.2.99-106

Gonçalves RFDM, Barreto DDA., Monteiro PI, Zangeronimo MG, Castelo PM, van der Bilt A, Pereira LJ (2019). Smartphone Use While Eating Increases Caloric Ingestion. Physiol. Behav. 204(October 2018). 93-99. https://doi.org/10.1016/j.physbeh.2019.02.021.

Hadianfard AM, Mozaffari-Khosravi H, Karandish M, Azhdari M. (2021). Physical Activity and Sedentary Behaviors (Screen Time and Homework) Among Overweight Or Obese Adolescents: A Cross-Sectional Observational Study in Yazd, Iran. BMC Pediatrics. 21(1): 1-10. https://doi.org/10.1186/s12887-021-02892-w.

Higgs S (2015). Manipulations of Attention During Eating and Their Effects On Later Snack Intake. Appetite. 92: 287-294. https://doi.org/10.1016/j.appet.2015.05.033

Internet World Stats (2021) World Internet Users Statistics. World Population Stats. Usage And Population Statistics. https://www.internetworldstats.com/stats.htm.

Jiang XX, Hardy LL, Ding D, Baur LA, Shi HJ (2014). Recreational Screen-Time Among Chinese Adolescents: A CrossSectional Study. J Epidemiol. 24(5): 397-403. https://doi.org/10.2188/jea.JE20140006.

Karmani, Ni-Nyoman KISG, Suparyatha I B, Pratiwi IGAPE. (2018). Prevalensi dan faktor risiko overweight or obesitas pada anak dan remaja vegetarian di Bali (Prevalence and risk factors of overweight/obesity in vegetarian children and adolescents in Bali). EJurnal Medika. 7(12): 1-7. https://ojs.unud.ac.id/index.php/eum/article /view/44597/27055.

Li L, Shen T, Wen LM, Wu M, He P, Wang $\mathrm{Y}, \mathrm{Qu} \mathrm{W}$, et al. (2015). Lifestyle Factors Associated With Childhood Obesity: A Cross-Sectional Study in Shanghai, China. BMC Res Notes. 8(1). 1-8. https://doi.org/10.1186/s13104-014-0958-y

Mazidi M, Banach M, Kengne AP (2018). Prevalence Of Childhood And Adolescent Overweight and Obesity in Asian Countries: A Systematic Review and Meta-analysis. Arch Med Sci. 14(6): 1185-1203. https://doi.org/10.5114/aoms.2018.79001.

Mistry SK, Puthussery S (2015). Risk Factors Of Overweight And Obesity In Childhood And Adolescence In South Asian Countries: A Systematic Review Of The Evidence. Public Health. 129(3): 200-209. https://doi.org/10$.1016 /$ j.puhe.2014.12.004.

Moradi G, Mostafavi F, Azadi N, Esmaeilnasab N, Nouri B (2016). Evaluation Of Screen Time Activities And Their Relationship With Physical Activity, Overweight and Socioeconomic Status In Children 10-12 Years Of Age In Sanandaj, Iran: A Cross-Sectional Study In 2015. Med J Islam Repub Iran. 30(1): 448. http://www.ncbi.nlm.nih.gov/pubmed/28210613.

Nawab T, Khan Z, Khan I, Ansari M (2014). Influence of behavioral determinants on the prevalence of overweight and obesity among school going adolescents of Aligarh. Indian $\mathrm{J}$ Public Health. 58(2): 121. https://doi.org/10.4103/0019-557X.132289.

Nguyen PVN, Hong TK, Nguyen DT, Robert AR (2016). Excessive Screen Viewing Time By Adolescents And Body 
Mayarestya et al./ Screen Time and the Risk of Overweight in Children and Adolescents

Fatness In A Developing Country: Vietnam. Asia Pac J Clin Nutr. 25(1): 174-183. https://doi.org/10.6133/apjen.2016.25.1.21

OECD/WHO (2020). Health At A Glance: Asia/Pacific 2020. In World Health Organization. 6011(24312). OECD. https://doi.org/10.1787/26boo7cd-en

Oflu A, Yalcin SS (2019). Video Game USe Among Secondary School Students And Associated Factors. Arch Argent Pediatr. 117(6): E584-E591. https://doi.org/10.5546/aap.2019.e584

Piryani S, Baral KP, Pradhan B, Poudyal AK, Piryani RM (2016). Overweight and its associated risk factors among urban school adolescents in Nepal: A cross-sectional study. BMJ Open. 6(5): e010335. https://doi.org/10.1136/bmjopen-2015-010335

Staiano AE, Harrington DM, Broyles ST, Gupta AK, Katzmarzyk PT (2013). Television, Adiposity, And Cardiometabolic Risk In Children And Adolescents. Am J Prev Med. 44(1): 40-47. https://doi.org/10.1016/j.amepre.201 2.09.049

Unantenne N (2014). Mobile Device Usage Among Young Kids:... https://scholar.google.com/scholar_lookup?title=
Mobile device usage among young kids\%3A a Southeast Asia study\&author $=$ N. Unantenne\&publication_year $=2014$

UNICEF (2020). Prevention Of Overweight And Obesity In Children And Adolescents. https://www.unicef.org/documents/prevention-overweight-andobesity-children-and-adolescents

Watanabe E, Lee JS, Mori K, Kawakubo K (2016). Clustering patterns of obesityrelated multiple lifestyle behaviours and their associations with overweight and family environments: A crosssectional study in Japanese Preschool Children. BMJ Open. 6(11). eo12773. https://doi.org/10.1136/bmjopen2016-012773

WHO (2020). BMI-for-age (5-19 years). In Growth Reference data for 5-19 years. https://www.who.int/tools/growthreference-data-for-5to19-years/indicators/bmi-for-age

$\mathrm{Xu} \mathrm{H}$, Wen LM, Rissel C (2015). Associations Of Parental Influences With Physical Activity And Screen Time Among Young Children: A Systematic Review. Int J Obes (Lond). 2015: 123. https://doi.org/10.1155/2015/546925 . 